\title{
The Recognition of Fragrant Plant Characteristic in Enhancing the Place Image for Royal Town of Kuala Kangsar, Perak
}

\author{
Intan Khasumarlina Mohd Khalid ${ }^{1}$, Osman M. Tahir ${ }^{2}$, Nor Atiah Ismail ${ }^{2}$, Zulkifli Muslim ${ }^{3}$ \\ ${ }^{1}$ Department of Landscape Architecture, Faculty of Design and Architecture, \\ Universiti Putra Malaysia, Serdang, Selangor, Malaysia \\ 1Department of Art and Design, Faculty of Art, Computing and Creative Industry, \\ Universiti Pendidikan Sultan Idris, Tanjong Malim, Perak, Malaysia \\ ${ }^{2}$ Department of Landscape Architecture, ${ }^{3}$ Department of Industrial Design, Faculty of Design and Architecture, \\ Universiti Putra Malaysia, Serdang, Selangor, Malaysia
}

marlyna2804@yahoo.com,osman_mtahir@yahoo.com, noratiah72@yahoo.com.sg, zulmuslim@yahoo.com Tel. 60176801844

\begin{abstract}
In Malay art, a flower or Bunga expressed about the beauties and aesthetics. At the same time, the fragrant plant belief to be a representative of paradise, which have a pleasant fragrance. It is observed that the used of aromatic plants has been a practices in Perak's royal ceremonies. This paper aims to identify the qualitative response on the recognition of the fragrant plant to support the reinforcement of place image of Kuala Kangsar as Royal Town of Perak. The results reveal that Lotus (Nelumbo), Melur (Jasminum), and Tanjong (Mimusops elengi) are mostly associated with Royal Town Kuala Kangsar, Perak. (100 words max.)
\end{abstract}

Keywords: Fragrant plant; Place Image, Royal Town

eISSN: 2398-4287 @ 2019. The Authors. Published for AMER ABRA cE-Bs by e-International Publishing House, Ltd., UK. This is an open access article under the CC BYNC-ND license (http://creativecommons.org/licenses/by-nc-nd/4.0). Peer-review under responsibility of AMER (Association of Malaysian Environment-Behaviour Researchers), ABRA (Association of Behavioural Researchers on Asians) and cE-Bs (Centre for Environment-Behaviour Studies), Faculty of Architecture, Planning \& Surveying, Universiti Teknologi MARA, Malaysia. DOI: https://doi.org/10.21834/e-bpj.v4i12.1874

\subsection{Introduction}

In Malaysia, there are several royal towns such as Bandar Maharani (Johor), Seri Menanti (Negeri Sembilan), Klang (Selangor), Arau (Perlis), Anak Bukit (Kedah), Pekan (Pahang) and especially Kuala Kangsar (Perak). According to Kuala Kangsar Municipal Council (MPKK), the Royal Town of Kuala Kangsar almost battered by the uncontrolled urban development and modernity (Harun, Fairuz, \& Nordin, 2015). However, over the years, there has not been much tourism development in Kuala Kangsar because of the limitation of space and elimination of the boundaries to keep Royal Town Kuala Kangsar as a tourist attraction (Ramli, 2015). Furthermore, based on direct observation, it is due to the lack of uniformity development, no continuity of streetscape elements from the main road to the town, and entrance to Iskandariah Palace of the Royal Town. Previous research also found that the uniqueness of royal tourism of Kuala Kangsar is essential as it visualized and portrayed the value of the royal cultural heritage and the existent of the monetary institutions (Othman, Illani, Razak, \& Ishak, 2014). The plant is one of the elements of cultural heritage for a place. The fragrant plant is a belief to be a representative of paradise, which is said to have a pleasant fragrance (Kamil \& Yunos, 2015). It is noticed that the used of aromatic plants has been a practice in some of Perak's royal ceremonies, such as 'meminang,' 'belimau' bath, 'bernikah,' and 'bertindik' (Jelani.H., 2011; Tung.A., 1999). Hence the fragrant plants could be an image representing the Royal Town of Kuala Kangsar, Perak. At the same time, it is observed that the image of the royal town almost decaying because of urbanization. The rapid globalization is known as a significant cause that hit the place image of the Royal Towns around the world. This issues is not only matter in the local context but

eISSN: 2398-4287 @ 2019. The Authors. Published for AMER ABRA cE-Bs by e-International Publishing House, Ltd., UK. This is an open access article under the CC BYNC-ND license (http://creativecommons.org/licenses/by-nc-nd/4.0). Peer-review under responsibility of AMER (Association of Malaysian Environment-Behaviour Researchers), ABRA (Association of Behavioural Researchers on Asians) and cE-Bs (Centre for Environment-Behaviour Studies), Faculty of Architecture, Planning \& Surveying, Universiti Teknologi MARA, Malaysia. DOI: https://doi.org/10.21834/e-bpj.v4i12.1874 
also around the world such as; 1)Royal Town Sutton Coldfield in the United Kingdom (Sutton Coldfield Civic Society, 2015); 2) Shenyang Imperial Palace in Beijing imperial deteriorated by the undergoes massive urban environment transformation (Cheng \& Kuo, 2015); 3) Royal Palace of Angkor Thom in Cambodia faded due to the fluctuations of a tropical climate have primarily erased the residences, as well as 4) Bayon Temple, ruined after the construction of the royal capital (Chandler \& Polkinghorne, 2017); (Ichita et al., 2016) and 5) Petropolis Imperial City in Brazil which changed to adapt the new uses, growth, and structures (Silva, 2016). Hence, this paper aims to identify the qualitative response on the recognition of fragrant plants to support the reinforcement of place image of Kuala Kangsar as Royal Town of Perak with the objective to study the fragrant plant's characteristics that could be used as a place image of this Royal town.

\subsection{Literature Review}

Place identity is referring to the contribution of place to one's identity through the meanings and values symbolized by place features. It is generally used to describe and interprets a subjective feeling and relationship between the environmental character as well as the people's perceptions about the cultural and physical environment (Twigger-Ross et al., 2003). Moreover, theories explaining place identity are varied. Lynch (1981) defines place identity as the extent to which a person can realize or remind of a place as being distinct from other sites. Therefore, it established the bonds between an individual and the area in the context of perception and cognitive representation of a place (Brown, Perkins, \& Brown, 2003; Rollero \& De Piccoli, 2010). While, Contrell (2010) assumes place identity and experience are examined through the notion of landscape, which the character is natural, built, and time. Previous research has shown that there is increasing interest in emphasizing the perception, and places are not new (Giuliani \& Feldman, 1993). Prior studies stated that the emotional bonding as place rootedness(Tuan, 1980); sense of place (Farnum, Hall, \& Kruger, 2005); place dependence (Stokols \& Shumaker, 1981), place bonding (Hammit, Kyle, \& Oh, 2009) and place attachment (Williams \& Vaske, 2003). Place identity in the context of this study refers to the meaning and values of place features to one's identity. In other words, it used to portray a personal feeling of identification of community living based on the physical, emotional, and behavioral characteristics in the Royal Town of Kuala Kangsar (Giuliani \& Feldman, 1993; Ujang, 2012). In this study, place identity stance through the visual element, which symbolized the cultural associate to the people live that can portray the unity of the Royal Town character. The distinctiveness, continuity, recognition, self-esteem, self-efficacy (Breakwell, 1986; Ginting \& V. Rahman, 2016) and aesthetic are five characters that visualized through the fragrant plant to enhancing place identity.

\subsection{Significant Used of Fragrant Plants in the Malay Way of Life}

Plants are significant indicators that contribute to an aesthetic-visual quality, which manifested the human-nature relationship over time. (Kro" nert, Steinhardt, \& Volks, 2001). There are several pieces of evidence found that the reward of good deeds according to the holy Quran is a place of shaded trees, flowing water, gardens with sweet fruits, and fragrant flower (Kamil \& Yunos, 2015). For instance, Mohd Hussain, Hassan, \& Mt Akhir (2016) found that the practice of appreciating flower fragrance could be a representative of paradise, which is also said to have a pleasant fragrance. It is further elaborated by Hafizah et al. (2014), who describe 'heaven' as a symbol of an area that includes a space advantage, where there are plants, flowers, fruits, and also the animals. Fragrant flowers noted as one of the elements mentioned in the Holy Quran as an adornment in heaven to emphasize its heavenly characteristic. Some studies found that fragrant plants are mostly used and adopted in the traditional Malay landscape to portray Islamic concepts and elements (ibid). Moreover, Harun, Mohd Ariffin, \& Abdullah (2017) found that diverse species of plants are related to everyday activities in a traditional Malay house. Whereby, Ramle, Shuaib, Abdullah, \& Mat Rasat (2014) states that the type of plants growing in the Malay village has specific functions that are beneficial in the Malay daily of life such as fruit trees, herbs, or medicines.

Several old Malay manuscript studies found that plants grouped into four main categories based on their functions and values. Prior studies of fragrant plants have found through establishing the Malay Traditional landscape together with the Islamic garden concept for future considerations (Hussain et al., 2016). These plants planted in the front yard of traditional Malay houses to provide a sense of welcome to the guests as well as to accentuate the appearance of the house (Zakaria, Salleh, \& Rashid, 2014). Moreover, the local people appreciated both beautiful and fragrant flower plants such as Kenanga, Kesidang, and Jasmin (Zakaria et al., 2014); Rose (Fatos (2011); and Cempaka, Tanjong, Lotus (Hafizah et al. (2014); and Kemuning Cina (Salleh, Rashid, \& Sakip, 2016); and Bayam, and Crataeva Hussin et al. (2012). Admittedly, fragrant flowers also used in Malay traditional medicinal practices such as for flower bathing ceremonies except for Nerjas, Tanjung, and Kemboja (Mustafa, Mohd \& Sarbini-zin, 2014). The beautiful Hibiscus rosa Chinensis flower is one of the ingredients in traditional medicine to remove wind and reduce headaches. Due to its flashy colors, sweet fragrances, and beautiful shapes, they generally used in the "Istiadat Berlimau" and "Mandi Sampat" ceremonies (Harun .J., 2009). Tung.A. (1999) mentioned that flowering scented plants often being used as 'air mawar' and 'bunga rampai' in several of royal Perak ceremonies. Notably, the scented flowers are usually used in the preparation of 'air mawar' and 'bunga rampai' such as Rose, Frangipani, Daisy, Jasmine other than Pandan leaves. Kendal, William, \& William (2012) surmised that people choose plants with both aesthetic traits such as flower size, leaf width, and foliage color as well as non-visual traits such as nativeness and drought tolerance. Above all, there is a growing need to determine the local community's' belief that influences the internal image of the Royal Town by the fragrant plant character. 


\subsection{Method}

\subsection{Study Area}

Kuala Kangsar is selected for this study because it is a convenient location; it holds a unique heritage of the Perak Malay Sultanate. It contains a much historic building associated with the royal legacy heritage. Furthermore, the town has officially declared as the Perak Royal City since 1887 (Shen, Farid, \& McPeek, 2008). The Royal Town of Kuala Kangsar is located in the State of Perak and situated in the north of Peninsular Malaysia between Ipoh and Taiping. The town today is bypassed by the North-South Highway and has become a backwater of tourism. It is $35 \mathrm{~km}$ north of Ipoh, the State Capital, and situated on the western bank of the Perak River. From Ipoh, the highway passes through karst topography dominated by rounded limestone hills blanketed in unique vegetation that can survive the harsh conditions.

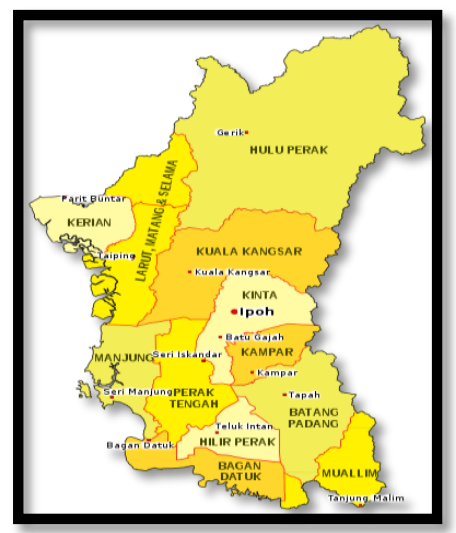

Fig. 1: Perak State Map (Source: Wikipedia.com)

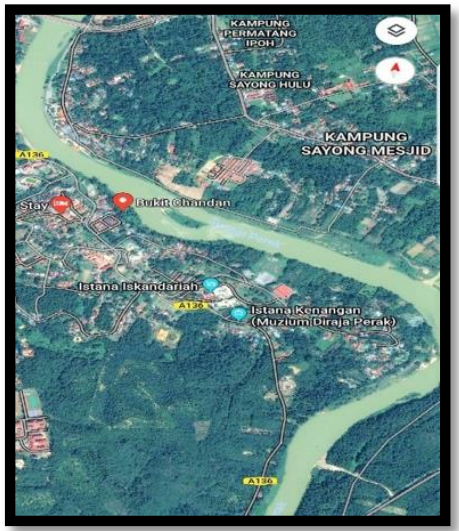

Fig. 2: Royal Town of Kuala Kangsar, Perak (Source: Google Map)

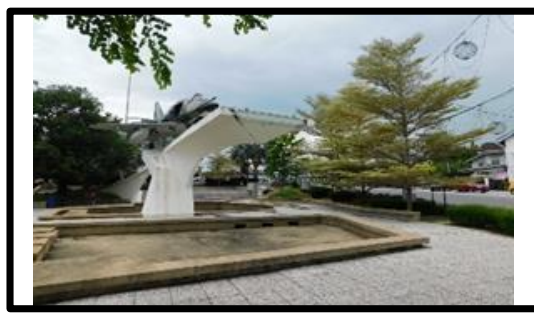

Fig 3 : Dataran Putra (Source: Author)

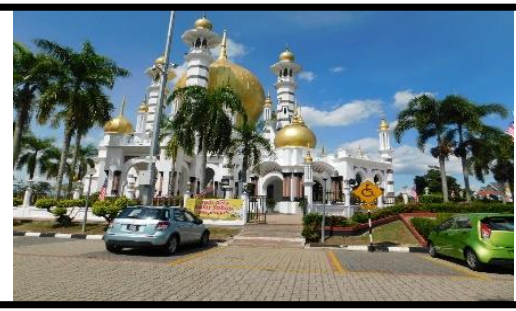

Fig 4: Ubudiah Mosque (Source: Author)

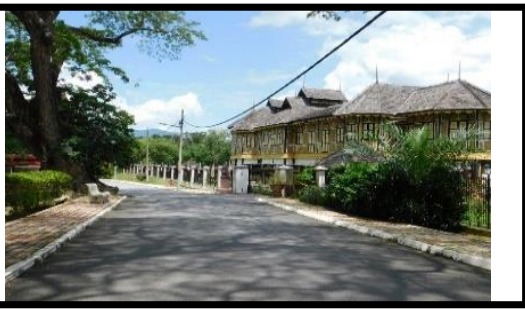

Fig 5: Kenangan Palace Source: Author)

This study adopts a case study research. Yin's (2003) explanation of the case study has been amended for architectural research by Groat and Wang (2013). In particular, Groat and Wang (2013), believes that a case study is an empirical inquiry that investigates a phenomenon or a setting, so it is particularly useful in the field of urban design. In this study, all data are collected within the boundary of the Royal Town of Kuala Kangsar, Perak, as a site case. The focus is on the streetscapes near Bukit Chandan streets; Jalan Taiping, Jalan Daeig Sedili, Jalan Istana, and Jalan Syahbandar. This study focuses on exploring the context of place identity, originality of royal town regarding the traditional landscape elements, through the fragrant plant as an embellishment of the city's streetscapes. This study identifies the importance of traditional plants used as an image to represent the people, background history, and the influences of socioculture in the plant's selection and its characteristics.

\subsection{Data Collection}

This study engaged with a semi-structure interview method. The respondents were twelve local peoples resided in the Royal Town of Kuala Kangsar. They are categorized into three groups consisted of; five professionals, two policymakers, and five skilled practitioners. This study used a qualitative case study that included a literature review as secondary data and semi-structured interviews. Therefore, to streamline the discussion, first, the respondents were asked to write down their biodata as part of the respondents' characteristics. Then proceeded to give their responses to the several discussion topics prepared previously. The type of plants coded is based on the name of the plant provided by the respondents until it achieved the saturated data. The respondents answer the questions based on their knowledge, experience, place background, and observation of the Kuala Kangsar environment.

The data obtained from these twelve respondents are categorized into the following topics, as shown in Table 1. 
Table 1. Interview Topics, Questions and Prompt Questions for In-Depth Answer

\begin{tabular}{ll}
\hline Topics & Research Questions \\
& Column $B(t)$ \\
\hline Fragrant plants & 1 Can You list the name of the plant that you familiar seen \\
& here? \\
& 2 Where did you see the plants? \\
& 3 Can you explain why the plants have been chosen? \\
& 4 Is it the plant that has strongly connected with Kuala \\
& Kangsar? \\
& 5. Why did you say that? \\
6 Did you think that plants have any specialty? Which part of \\
the plant? \\
(Source: Author)
\end{tabular}

Later, the researcher analyses the connection of the fragrant plants with the place, recognizing the plants and how it could enhance the place identity of the royal town of Kuala Kangsar Perak.

\subsection{Data Analysis Procedure}

One of the most challenging difficulties involving case study evidence is data analysis that deals with the amount and variety of information (Yin, 2003, p. 109). According to Yin (2003), these difficulties can be reduced if the research has a general strategy for data analysis. Among all the strategies suggested by Yin (2003), this particular research considered "relying on theoretical propositions."

The theoretical proposition obtained in the literature review not only led the data collection process but also helped to organize the data gathered for the research questions and the data analysis in this study. Therefore, the collected information's were further categorized and analyzed in three main areas, namely, data concerning the place identity of the royal town, information concerning the factors related to plant and its relationship with place, and the authenticity of plants as a symbolism of place identity of the royal town Kuala Kangsar, Perak.

The data analysis procedure consists of 4 stages. 1) Preparing data for analysis; 2) Exploring the data; 3) Analyzing the data and 4) Presenting the data analysis. Each step of the analysis consists of the detail process of developing the results, as shown in Figure 6 below.

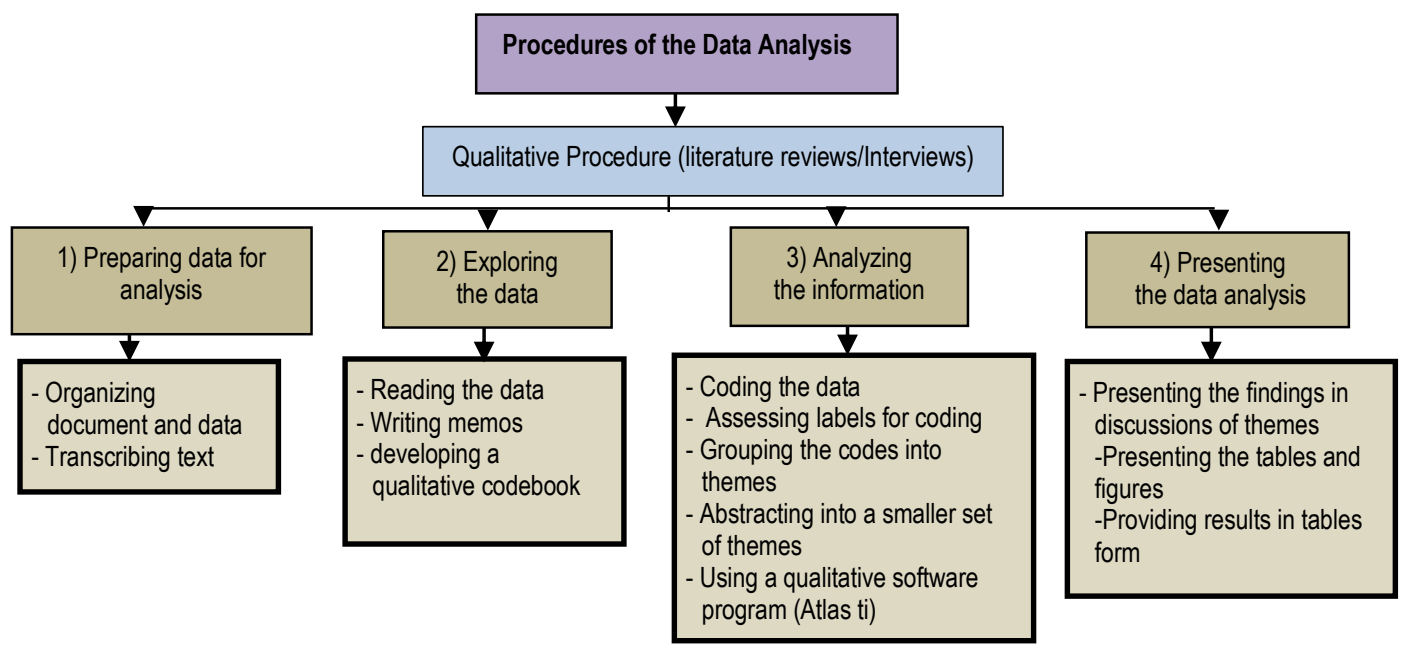

Fig 6: Data analysis procedure (adapt from Cresswell 2007)

\subsection{Findings}

The first set of questions aimed to identify the plant criteria constitute for Kuala Kangsar, Perak. The interview conducted is to investigate the respondents' opinions on the issues of the plant as an adornment in the royal town. The topics discussed according to two questions: the development of the royal town concerning the type of plant selected, and the relationship of the plant with Kuala Kangsar, Perak.

Firstly, the result shows that all the respondents believed that the development of the Royal Town of Kuala Kangsar did not follow the type of plant related to the Kuala Kangsar town but is based on the Malay ancestor plant. It is because the type of plants often used as an ornament plant in traditional Malay village is also used in traditional ceremonies as well as in the Royal ceremonies. The findings also reveal that because of their popularity among the villager, it was chosen as a subject matter to embellish on the local craft of Kuala Kangsar. Besides that, the respondents noted that the plant with scented consumes attention to the royal environment. Therefore, the respondents' opinions confirm the importance of the royal town environment on the recognizable of specific criteria in terms of soft capes 
element. The respondents stressed that the reason why the plants were selected is highly related to the background of the royal town, its cultural, authenticity, tradition, and the aesthetic value of the plants.

\subsection{Fragrant Plant}

Based on the first question sequential, it leads to the second question, which is the type of fragrant plants. The respondents are asked if there is any relationship between the traditional plants with the scented plants. Besides the theme derives from the literature, the fragrant plant is under the traditional plant that can build the character of the plant in the royal town. The respondent approved there is the list of the fragrant plant under these criteria. In a similar vein, the respondent listed the name of traditional plants that has a scented character, and the part of the flower highlights. Respondent believed the scented garden would give the town its dispositions. This is because flowers and blooming plants have significant benefits in the royal town environment. In short, except vision, no sense is as closely tied to memory as the sense of smell. Thus, smelling floral scents has the extraordinary power to put people in a good mood and feel less anxious. Interestingly, the respondent claims that these are the type of scented plants suitable for the royal town environment. It expresses the feeling of a traditional village garden

The result of the interview reveals that $43 \%$ of the respondents agreed that the Melur flower has specific criteria appropriate for the royal town. "In the gardens, we try to create an area where the name is the fragrant park ... the people will realize the scent when they reach one area of the park."(PM1)

This followed by Bunga Tanjong (33\%), as the plant needs to be a highlight in Kuala Kangsar. The nature of the plant is fragrant and uniquely emphasizes the authenticity of the traditional plant. Most of the respondent believes that Bunga Tanjong is the type of plant have both specific criteria. It is a beautiful flowery and fragrant plant. This strong factor lifts the plant as the recognition of the royal town plant. "Most of the flower is in the palace like Tanjong Flower, sometimes decorated on the cushion" (PR4)

At the same time, $24 \%$ of the respondent agreed that the Lotus flower $(24 \%)$ need to highlight as a scented plant.

"The flower motif mostly you will find in the palace environment indoor and outdoor. The same motif always repeated as a decoration." (PR2)

In summary, the experts agreed that the process of planning the element of plants in the royal town needs to be more related to the culture of local people. Furthermore, the uniformity of the plants selected needs further concern. Some of the respondents remarked that the legal boundaries in the royal town limit the consistency of the royal town concept. It indirectly weakens the design function of the royal town. The result also suggests that the nature of the fragrance plants able to self-uplifting, creating a desire for life and giving it a memorable impression.

Figure 7 represents the summary of the recognize fragrance plant for the royal town.

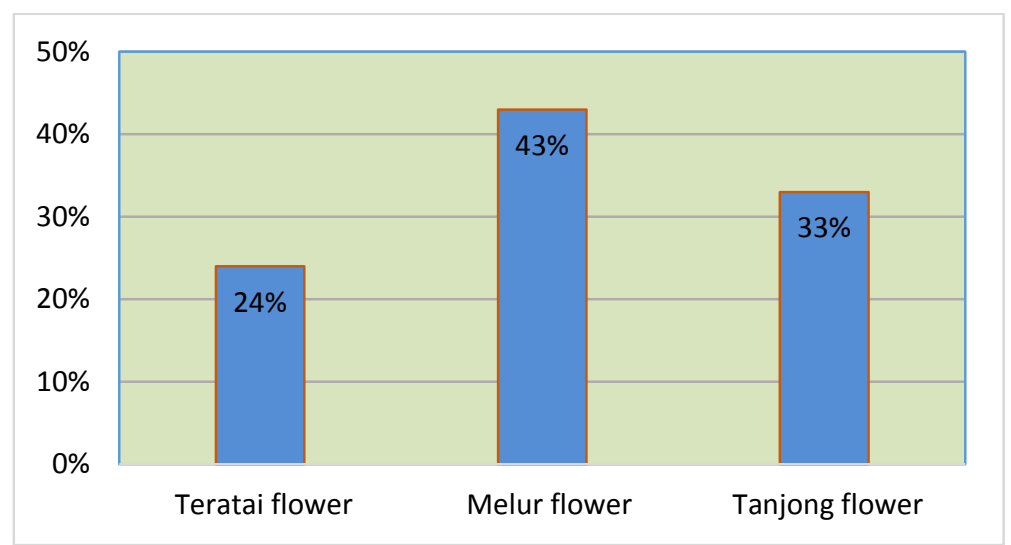

Fig. 7: Recognition of fragrance plant as criteria in the royal town (Source: Author)

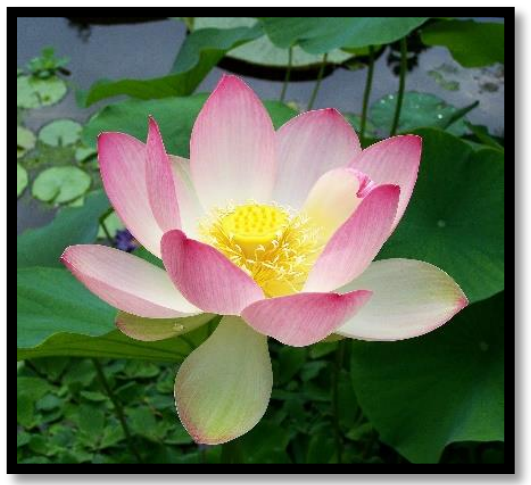

Fig 8; Bunga Lotus (Nelumbo nuciefera) (Source: Wikipedia.com)

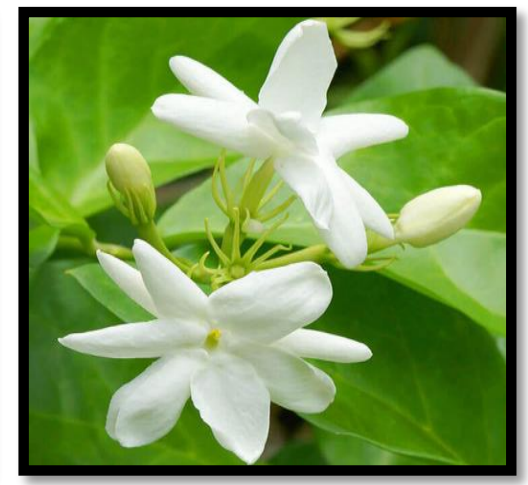

Fig 9: Bunga Melur (Jasminum sanbac) (Source: Wikipedia.com)

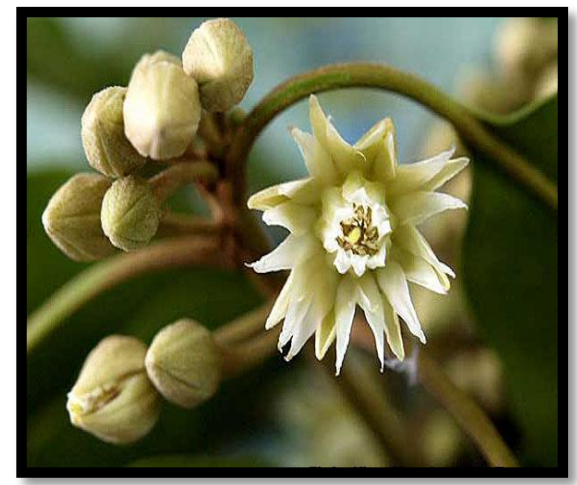

Fig 10: Bunga Tanjong (Mimosops elengi) (Source: Wikipedia.com) 


\subsection{Discussions}

Respondents in this study suggested several types of plant criteria suited as the symbolic motifs for the study area. However, fragrant flowering plants have a unique character suitable for a royal town. Most of them specifically suggested that the plants commonly used in Malay traditional culture should be appropriate in symbolizing the royal town.

This fits in well with the conceptual framework of this study. The themes suggested by the respondents include the following:

a) Traditional fragrant plants commonly used by the Malay community for many generations, i.e., Bunga Tanjong (Mimosop elengi).

b) Plants that traditional local people are familiar, i.e., Bunga Melur (Jasminum sambac)

c) Fragrant plants under the unique type of plant category, i.e., Bunga Lotus (Nelumbo nucifera).

The results of this study indicate that traditional societies frequently use aromatic flowering plants as ornamental plants. This finding is consistent with Tabuti et al. (2003) and Chiranjibi et al. (2006), who found that the use of the traditional plant in developing countries contributes directly to the socio-economic status and well-being of the rural communities. Furthermore, aromatic plants are necessarily required in the Perak Sultanate ceremonies such as wedding, death, and medicine. Traditional Malays also used fragrant flowers in the floral bath or "mandi bunga" rituals to cleanse themselves of evil spirits (Mustafa, Mohd, \& Sarbini-zin, 2014); (Harun.J., 2009).

From the study, respondents also agreed that fragrant plants should be planted along Jalan Istana, leading to the Istana Iskandariah (Iskandariah Palace). Others suggested fragrant plants that are used by the rural Malay communities need to be planted as a landscape tree in the town. Other respondents agreed that fragrant plants should be used as they are mentioned in the holy Quran to describe paradise (Surah Ali-Imran; 191 and Surah Al-An'am; 99)

The practices of a society can, over time, become a hereditary culture of that society. This supported the notion that the relationship between plants, the environment, and society contributes to the stability of a place. This inline with Relph (1976), who states that the people, associations, and places have the development potential that reflects the human experience. This further supports the idea of recognizing a special place like this study area. A possible explanation for the choice of fragrant plants by respondents could be that they are commonly used to embellish the Labu Sayong, which is a local craft associated with the study area. Symbols are related to nature, culture, emotional bond, and the meaning of a place (Hay, 1998), as well as they, can create a feeling of pride (Twigger-Ross et al., 2003).

Furthermore, fragrant plants are also used in royal wedding ceremonies of the Perak of Sultanate. This is to ensure the continuity of the royal lineage and unity of royal relations. As stated by O'Donnell (2008), fragrant plants are icons of place memory and heritage value.

One of the interesting findings from this study is that the Bunga Lotus (Nelumbo nucifera) is recognized as a royal plant by one of the craft makers. The reason being that the large flower size represents the richness of the royalty, and its white color symbolizes the greatness and majesty of the Sultan of Perak. Colors, like shape and form, reflects the splendor and beauty of aesthetical elements or ornamentations adorning them and carry more profound philosophical association and meaning ((Aziz \& Olalere, 2013; Shuaib \& Enoch, 2014). This situation translates that these plants have a substantial relationship with the memories of the past, primarily related to people, culture, and place. The respondent's experience shows that the selected plants are the type of plant that people can recognize the Royal Town of Kuala Kangsar. Furthermore, the color of the flowers, well known among the local people and being used in many of the Royal Perak Institution ceremonies, are other reasons for the plants suitable to represent the royal town of Kuala Kangsar, Perak.

\subsection{Conclusion \& Recommendation}

This study set out to identify the recognition of fragrant plants for place identity of the royal town of Kuala Kangsar, Perak. Data collected may help to preserve knowledge about different traditional plants used by the respondent as a people of Kuala Kangsar and their mode of use for visualizing an image of a place. Looking at a flower is a happiness source. But flowers and blooming plants have other great benefits for the royal town environment. Except for vision, no sense is as closely tied to memory as the sense of smell. Thus, smelling floral scents has the extraordinary power to put people in a good mood, feel less anxious, and bring back a memory from the past. Also, the fragrant plant can make people's life easier and more pleasant through the senses, make people feel better and released as well as can represent the Royal Town of Kuala Kangsar, Perak. The results of this study revealed Bunga Melur, Bunga Tanjong, and Bunga Lotus are the three most considerable plants suitable to be used for imaging the place and people. These flowers produce substantial benefits for the royal town of Kuala Kangsar environment. These plants can be a symbol of the area and related to the cultural significance of Kuala Kangsar. Eventually, both visual beauty and smell are essential for enhancing the place identity of the royal town of Kuala Kangsar Perak. This study could be a 'benchmark' for other research to be carried out in other royal city in Malaysia. Further study on the characteristics of fragrant plants and the establishment of the criteria of plants for the royal town of Kuala Kangsar, Perak, is recommended.

\section{Acknowledgment}

This research has been made possible with the funding from the Geran Putra; Vote: 9586500 under the Research Management Centre, Universiti Putra Malaysia, Serdang Selangor, Malaysia. 


\section{References}

Aziz, A. S., \& Olalere, F. E. (2013). Integrating Malay Tangible Cultural Heritage into Furniture Design: An Approach to Enhance Product through Emotional and Spiritual Contents. The Online Journal of Science and Technology (TOJSAT), 3(4), 77-85

Brown, B., Perkins, D. D., \& Brown, G. (2003). Place attachment in a revitalizing neighborhood: Individual and block levels of analysis. Journal of Environmental Psychology, 23, 259-271

Breakwell, G.M., 1986. Coping with Threatened Identities. Methuen, London.

Chandler, T., \& Polkinghorne, M. (2017). A Review of Sources for Visualising the Royal Palace of Angkor, Cambodia, in the 13th Century. In S. Hoppe, S. Breitling, \& W.T.A.O.H. Messemer (Eds) (Vol. 3, pp. 149-170). Palatinum.

Cheng, C., \& Kuo, H. (2015). Bonding to a new place never visited : Exploring the relationship between landscape elements and place bonding. Tourism Management, $46,546-560$

Chiranjibi, P., Sudhakar, R., Dhal, N.K., Rashmita, D. (2006). Some phytotherapeutic claims by tribals of Rayagada district, Orissa, India. Ethnobotanical Leaflets 10 , 189-197.

Cresswell, J. W. (2007). Qualitative inquiry \& thesis design: Choosing among five approaches (2nd ed.). California: Sage Publications, Inc

Farnum, J., Hall, T., \& Kruger, L. (2005). Sense of Place in Natural Resource Recreation and Tourism: An Evaluation and Assessment of Research Findings (Vol. PNW-GTR-66).

Fatos, A. (2011). Islamic gardens with a special emphasis on the Ottoman paradise gardens: The sense of place between imagery and reality. Online Journal of Communication and Media Technologies, 1(4): 55-96

Ginting.N. \& N.V.Rahman. (2016).Maimoon Palace Heritage District in Medan, Indonesia: What we preserve and why we preserve?. Journal of Social and Behavioral Sciences 222 ( 2016 ) $332-341$.

Giuliani, M., \& Feldman, R. (1993). Place attachment in a developmental and cultural context. Journal of Environmental Psychology, 13, 267-274.

Groat.L \& D. Wang (2013). Architectural Reseach Methods (2nd edition). John Wiley \& Sons

Hammit, E., Kyle, G., \& Oh, C. (2009). Comparison of Place Bonding Models in Recreation Resource Management. Journal of Leisure Research, 41(1), 57-72.

Harun, N. Z., Fairuz, D. N., \& Nordin, N. A. (2015). The roles of Urban Heritage in determining the image of the Royal Town of Sri Menanti, Negeri Sembilan. Planning Malaysia, 13(November 2016), 85-100.

Harun, N. Z., Mohd Ariffin, N. A., \& Abdullah, F. (2017). Changes and threats in the Preservation of the Traditional Malay Landscape. Planning Malaysia, 15(2017), 6978.

Ichita et al. (2016). The Advanced Hydraulic City Structure of the Royal City of Angkor Thom and Vicinity Revealed through a High- Resolution Red Relief Image Map. Archaeological Discovery, 04(01), 22-36.

Jelani Harun. (1999). Nuruddin al-Raniri's Bustan al-Salatin: A Universal History and Adab Work from Seventeenth-Century Aceh. (Unpublished doctoral dissertation). London: School of Oriental and African Studies.

Jelani Harun. (2009). Bustan Al-Salatin: The Garden of Kings: A Malay Mirror for Rulers. Pulau Pinang: Penerbit Universiti Sains Malaysia

Kamil, S. M., \& Yunos, M. Y. M. (2015). Establishing Malaysia Islamic Garden-Based On Quranic Paradise Imagery: Descriptive Analysis From Tafsir Surah Waqiah. Advances in Environmental Biology, 9(23), 115-119.

Kendal, D., William, K., \& William, N. (2012). Plant traits link people's plant preferences to the composition of their gardens. Landscape and Urban Planning, 105((1-2)), $34-42$.

Kro" nert, R., Steinhardt, U., \& Volks, M. (2001). Landscape Balance and Landscape Assessment (Vol. 8). Springer -Verlag Berlin.

Lynch, K (1981) A Theory of Good City Form. MIT Press, Cambridge, MA

Mohd Hussain, N. H., Hassan, K., \& Mt Akhir, N. (2016). Establishing the Malay Landscape Elements through Islamic Garden Perspective. Environment-Behaviour Proceedings Journal, 1(3). https://doi.org/10.21834/e-bpj.v1i3.306

Mustafa, Mohd \& Sarbini-zin. (2014). Amalan Perubatan tradisional Masyarakat Melayu Sarawak. Journal of Social and Behavioral Sciences (134), 316 - 322 ICLALIS

O'Donnell, P. M. (2008). Urban cultural landscapes and the Spirit of Place, Presented in 6th ICOMOS General Assembly and International Symposium, September 2008, Quebec, Canada.

Othman, R., Illani, N., Razak, A., \& Ishak, N. (2014). Ethnobotanical Study of Traditional knowledge on Plant Used in Traditional Bath (Mandiserom ) among Malay Midwives in Perak and Negeri Sembilan. Research Journal of Biological Sciences, 9, 193-196.

Ramle, N. H., Shuaib, A. A., Abdullah, R., \& Mat Rasat, M. S. (2014). Islamic Elements of Plants Selection on Malay Landscape in Kota Bharu City. Australian Journal of Basic and Applied Sciences, 8(82), 265-271. Retrieved from www.ajbasweb.com 
Ramli, N. (2015). Keep Kuala Kangsar Naturally Beautiful. News Straits Times Press (M) Berhad.

Hay, R. (1998). Sense of place in a developmental context. Journal of Environmental Psychology, 18,5e29.

Relph, E. (1976). Place and Placelessness (London, Pion)

Rollero, C. \& De Piccoli, N. (2010). Place attachment, identification and environment perception: An empirical study. Journal of Environmental Psychology (article in press).

Salleh, I. H., Rashid, M. S. A., \& Sakip, S. R. M. (2016). Malay Garden Concept from the Traditional Malay Landscape Design. Procedia - Social and Behavioral Sciences, 222, 548-556. https://doi.org/10.1016/j.sbspro.2016.05.213

Shuaib, A. A., \& Enoch, F. (2014). Integrating the Malay Traditional Design Elements into Contemporary Design : An Approach towards Sustainable Innovation. Procedia - Social and Behavioral Sciences, 129, 59-67. https://doi.org/10.1016/j.sbspro.2014.03.648.

Silva, E. (2016). The Hidden Petropolis Modernism. VIRUS 12, Radical Modern.

Stokols, D., \& Shumaker, S. (1981). People in Places: A Transactional View of Settings. In J. H. Harvey (Ed.), Cognition, Social Behavior, and the Environment (pp. (pp. 441-488).

Sutton Coldfield Civic Society. (2015). Sutton Coldfield High Street Conservation Area Character Appraisal and Management Plan: Character Appraisal and Management Plan Supplementary Planning Document. Birmingham City Council. https://doi.org/10.4324/9780080489025

Twigger-Ross, C.L., Bonaiuto, M., \& Breakwell, G. (2003). Identity theories and environmental psychology. In M. Bonnes, T. Lee \& M. Bonaiuto (Eds.), Psychological Theories for Environmental Issues (pp 203-233). Aldershot, England: Ashgate.

Tabuti, J.R.S., Dhillion, S.S., Lye, K.A. (2003a). Traditional medicine in BulamogiCounty, Uganda. Its practitioners, users \& viability. Journal of Ethnopharmacology 85 , 119-129.

Tabuti, J.R.S., Lye, L.A., Dhillion, S.S. (2003b). Traditional herbal drugs of Bulam- ogi, Uganda: plants, use, and administration. Journal of Ethnopharmacology 88, 1944.

Tuan, Y. (1980). Rootedness versus Sense of place. Landscape, 24(1), 3-8.

Ujang, N. (2012). Place Attachment and Continuity of Urban Place Identity. In Procedia - Social and Behavioral Sciences (Vol. 49, pp. 156-167).

Williams, D., \& Vaske, J. (2003). The Measurement of Place Attachment: Validity and Generalizability of a Psychometric Approach. Forest Science, 49, 830-840. Yin, R. K. (2003). Case Study Research: Design and Method (Vol. 5). London: Sage Publications.

Zakaria, A. Z., Salleh, I. H., \& Rashid, M. S. A. (2014). Identity of Malay Garden Design to be Promoted as the Cultural Tourism Product in Malaysia. Procedia - Social and Behavioral Sciences, 153, 298-307. https://doi.org/10.1016/j.sbspro.2014.10.063 